\title{
Quarterly Progress Report Characterization of Substances in Products, Effluents and Wastes from Synthetic Fuel Development Processes
}

January 1977

Prepared for the Energy Research and Development Administration under Contract EY-76-C-06-1830 


\title{
NOTICE
}

This report was prepared as an account of work sponsored by the United States Government. Neither the United Staies nor the Energy Research and Development Administration, nor any of their employees, nor any of their contractors, subcontractors, or their employees, makes any warranty, express or implied, or assumes any legal liability or responsibility for the accuracy, completeness or usefulness of any information, apparatus, product or process disclosed, or represents that its use would not infringe privately owned rights.

The views, opinions and conclusions contained in this report are those of the contractor and do not necessarily represent those of the United States Government or the United States Energy Research and Development Administration.

\author{
PACIFIC NORTHWEST LABORATORY \\ operated by \\ BATTELLE \\ for the \\ ENERGY RESEARCH AND DEVELOPMENT ADMINISTRATION \\ Under Contract EY-76-C-06-1830
}

\author{
Printed in the United States of America \\ Available from \\ National Technical Information Service \\ U.S. Department of Commerce \\ 5285 Port Royal Road \\ Springfield, Virginia 22151
}

Price: Printed Copy

$\because$ Microfiche $\$ 3.00$

$\begin{array}{cc}\text {-Pages } & \begin{array}{c}\text { NTIS } \\ \text { Selling Price }\end{array} \\ 001-025 & \$ 4.50 \\ 026-050 & \$ 5.00 \\ 051-075 & 55.50 \\ 076-100 & \$ 6.00 \\ 101-125 & \$ 6.50 \\ 126-150 & \$ 7.00 \\ 151-175 & \$ 7.75 \\ 176-200 & \$ 8.50 \\ 201-225 & 58.75 \\ 226-250 & 59.00 \\ 251-275 & \$ 10.00 \\ 276-300 & 510.25\end{array}$




\title{
QUARTERLY REPORT - FOURTH QUARTER 1976 \\ CHARACTERIZATION OF SUBSTANCES IN PRODUCTS, EFFLUENTS AND WASTES FROM SYNTHETIC FUEL DEVELOPMENT PROCESSES
}

\author{
J. S. Fruchter, M. R. Petersen, \\ and P. W. Ryan
}

January 1977

Prepared for the U. S. Energy Research and Development Administration under Contract EY-76-C-06-1830

Battelle

Pacific Northwest Laboratories

Richland, Washington 99352 
QUARTERLY REPORT, 4th QUARTER-1976

\author{
CHARACTERIZATION OF SUBSTANCES IN PRODUCTS, EFFLUENTS AND \\ WASTES FROM ŚYNTHETIC FUEL DEVELOPMENT PROCESSES \\ J. S. Fruchter, M. R. Petersen, and P. W. Ryan \\ Battelle \\ Pacific Northwest Laboratories \\ Richland, Washington 99352
}

Pacific Northwest Laboratories is working under contract with the Energy Research and Development Administration to characterize materials from promising synthetic fossil fuel processes. The objectives of this program are to identify and quantify the constituents occurring in products, effluents and emissions from the technology processes that warrant consideration in the development of control measures. A part of our program includes the collection, characterization, preservation, and storage of products, effluents, and wastes from these processes. These materials may then serve as "research materials" for more detailed characterization and for environmental and heal th effects studies. An important purpose served by the research materials is to permit laboratories to compare their results when carrying out various tests and studies with the materials. The program thus provides an essential element of quality control and validation of procedures to the health and environmental studies conducted by the laboratories.

These quarterly reports are intended to provide up-to-date information on the status of these characterization efforts to those concerned with emission control and to the biological and environmental scientists working in this area.

ORGANIC AND INORGANIC CONSTITUENTS IN THE SOLVENT REFINED COAL PROCESS

During this quarter, a second major set of samples was obtained from the SRC plant operated by Pittsburg and Midway Coal Mining Company at Fort Lewis, Washington. We thank the staff of the SRC plant for making the samples available to us for these studies. The samples included: (1) 100 liters each of light oil, wash solvent and recycle (process) solvent; (2) composite samples of feed coal and product; (3) a $50 \mathrm{~kg}$ sample of mineral residue; (4) some water effluent samples; (5) special samples for speciation analys is of arsenic and mercury in the gas streams; (6) organic aerosol material in the product 
-

$+$ 
cooling belt room during normal room ventilation; (7) the gases before flaring; and (8) particulates arising from the cooling product. Samples 1 and 3 are for the Research Materials Program described in Section III.

A partial mass balance of the total mercury in the SRC process indicates that of the mercury in the feedcoal $(0.16 \mathrm{ppm}), 8 \%$ remains in the solvent refined coa $1,0.3 \%$ in the mineral residue, $<1 \%$ in byproduct 1 iquids, and about $10 \%$ in the untreated process water. Thus, we felt the remaining mercury should be in volatile forms. Analytical procedures which have been demonstrated for analysis of mercuric ion, methyl mercury, dimethyl mercury, metallic mercury, and particulate mercury were used in the gaseous effluent stream just before flaring. At the detectable levels (about 1ng/liter for this particular sampling run) no mercury in any form was measurable. Since all these samples were not obtained simultaneously during a controlled mass balance period, the distribution of mercury in the SRC process is still uncertain; we do not yet have a complete mass balance.

Other compounds in the gaseous effluent prior to flaring were analyzed using gas chromatography/mass spectrometry (GC/MS). The compounds detected included carbon dioxide, hydrogen sulfide, the alkanes up to heptane, the alkenes up to heptene, and various aromatics including benzene, toluene, methylnapthalenes, biphenyl, dimethylnaphthalenes, acenaphthene, and dibenzofuran. The methylnatphthalenes were observed to be the predominant species in air obtained from the room that houses the Sandvik cooling belt.

The SRC pilot plant is scheduled to shut down at the end of January 1977, for modifications to the SRC-II process. The primary change in processing conditions between SRC-I and SRC-II is the recycle part of the unreacted coal solution and mineral material through the heating and dissolving step. This recycle increases the residence time of the higher boiling material in the coal solution. This change in the reaction conditions produces the liquid products of the SRC-II process. This process is designed to produce a low-sulfur residual oil equivalent to No. 5 or No. 6 fuel oil. Several other liquid products will be produced in smaller amounts - "naphtha" and a middle oil. Heavy bottoms and the undried mineral residue will be mixed, forming a solid mixture suitable as a gasifier feedstock. After tests are completed in late March and April, the SRC-II process should start producing residual oil during May. We plan to conduct characterization studies for the SRC-II process also. 
During the quarter we have developed a technique using reverse-phase high pressure liquid chromatography that permits a more detailed analys is of the compound types that are dissolved in aqueous effluents. We are using LiChrosorb RP-5 and RP-10 columns ( $C_{8}$ bonded on silica gel and available from Rheodyne, Berkeley, California) with water methanol gradient elution at flow rates $0.5-1.0 \mathrm{ml}$ minute. Phenolic, nitrogen heterocyclic and aromatic compounds are separated in a single 30-45 minute gradient program. Thus, these compounds can be analyzed directly in water by this method without any preseparation. This technique is particularly important for analyzing the phenols in process water from coal conversion facilities since it allows direct measurement at concentrations down to the ppm levels.

\section{DIRECT DETERMINATION OF POLYNUCLEAR AROMATICS (PNA) IN FOSSIL FUEL FRACTIONS}

A major breakthrough has been made in the direct quantitative analys is of several PNA species in the liquid SRC products. As a result, no chemical preparation or chromatographic separation is necessary prior to injection into the GC/MS instrument, and reliable measurements down to about $100 \mathrm{ppb}$ are obtained. Our laboratory has found that short $(1-6 \mathrm{ft}) \mathrm{GC}$ columns packed with $3 \%$ SP2100 + $0.3 \%$ SP 1000 liquid phases or 3\% SP2250 1iquid phase on HP Chromosorb $W$ 100-120 mesh are very efficient for PNA separations. These columns satisfactorily separate the benzopyrenes from other PNA's in run times as short as 4 minutes. However, these columns do not separate the two isomers benzo(a)pyrene and benzo(e)pyrene. Using these separations together with chemical ionization mass spectrometry analysis, which employs argon for charge transfer, yields large molecular ion signals from polynuclear aromatic compounds while causing very extensive fragmentation of other species of comparable molecular weight. Thus, interferences are essentially eliminated. In special cases the detection limit of this direct instrumental technique can be as low as $20 \mathrm{ppb}$.

This GC/MS technique has been applied to three composite $(5 / 13$ through $5 / 14$ 1976) SRC liquids to determine benzopyrene concentrations. The light oil (sample pt 408A) and wash solvent (sample pt 410) fractions contain nearly equal concentrations of benzopyrenes of $0.2 \mathrm{ppm}$. By way of comparison, the 


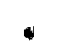


recycle solvent (sample pt 411), from which these two light fractions are distilled, contains 365 ppm benzopyrenes.

This is the first time that a technique for determining benzopyrenes at this level without prior chemical separation has been reported. By eliminating the complex separation procedure, this new technique will allow sensitive, accurate PNA determinations with significantly decreased analysis time.

\section{OIL SHALE AND TAR SAND EFFLUENT CHARACTERIZATION}

Several procedures have been developed which can be used to good advantage in characterizing the compounds that arise in retorting oil shale. The high pressure liquid chromatographic technique described previously is also suitable for analyzing many water soluble compounds, including $N$-heterocyclic compounds.

Our new chemical ionization technique based on the use of argon for charge transfer permits the direct analys is of polynuclear aromatic hydrocarbons, including benzopyrene, in shale oi1. A sample of shale $0 i 1$ from Run No. 13 of the Laramie 150-ton retort was found to contain $23 \mathrm{ppm}$ benzopyrenes. This concentration is comparable to the $30-40 \mathrm{ppm}$ values ${ }^{1}$ reported in colorado shale oils (oxidatively retorted NTU crude shale oil) but higher than $3.2 \mathrm{ppm}$ reported by Coomes (TOSCO-II shale 0i1). ${ }^{2}$

\section{TRACE ELEMENTS IN OIL SHALE MATERIALS}

During the quarter, we have completed trace element analys is on a number of oil shale materials. The data presented in Table I were obtained by using instrumental neutron activation, radiochemical neutron activation, $X$-ray fluorescence, and flameless atomic absorption. It can be seen that the two raw shales do not differ significantly in their trace element contents, even though one is a 15-galion/ton shale and the other assays at 40-gallon/ton. Since neither the spent shale nor the crude shale oil is from a run in which either raw shale was a feed-stock, a material balance cannot be constructed. Raw shale is enriched over average crustal rock abundances in Se, As, and Sb and somewhat enriched in $\mathrm{U}, \mathrm{Pb}, \mathrm{Cs}, \mathrm{Hg}$, and $\mathrm{Zn}$. Raw oil shale is depleted by about a factor of 5 in many refractory elements. Both the crude shale oil 


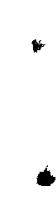


and water contain measurable concentrations of $\mathrm{Hg}, \mathrm{Ag}, \mathrm{Zn}$, Se, and $\mathrm{Co}$; and in addition, the water contains measurable $\mathrm{Br}, \mathrm{Sb}$, and $U$ (Table II). Measurement precisions associated with these elements are presented in Table III. We have obtained trace element data for filtered shale oil (0.45 micron filter) and four fractions of shale oil (neutral, basic, acidic, and polynuclear aromatic fractions). The data are shown in Table II. Most of the elements show considerable partitioning among the various fractions, al though $\mathrm{Se}$ is fairly evenly distributed. The As and $\mathrm{Hg}$ are more concentrated in the acidic fraction, while $C_{0}$ is mainly in the basic fraction. The $\mathrm{Zn}$ is relatively high in the acid, basic and PNA fractions, but markedly depleted in the neutral fraction. This behavior relative to the $\mathrm{pH}$ may be attributed to the amphoteric character of $\mathrm{Zn}$; however, the association with the PNA fraction suggests the presence of an organometallic compound. A mass balance elemental distribution has not yet been established since analysis for the isooctane-insoluble tar fraction is not complete. This fraction and several other elements in the other four fractions are being analyzed now.

\section{RESEARCH MATERIALS}

In this program we are collecting research materials from promising pilot operations and storing them in a manner to minimize degradation as stated above. These materials are stored under a nitrogen atmosphere at $-2^{\circ} \mathrm{C}$ in the dark in either teflon-lined stainless steel barrels or in brown glass bottles. The materials are characterized in considerable detail when they are received. We plan to determine the composition again at six-month and one-year intervals to see if significant degradation of organic compounds has occurred.

During this past quarter we have collected approximately 30 gallon samples of light oil (naphtha), wash solvent, recycle solvent, and dried mineral residue from the SRC process at Fort Lewis, Washington. We have also made arrangements to obtain a substantial amount of the solvent refined coal that was produced during this same time period. Fractions of these liquids have been made available for mutagenic screening in the Biology Department at this laboratory. 
-

$$
-
$$




\section{REFERENCES}

1. H. H. Cahnmann, Anal. Chemistry 27, 1235 (1955).

2. R. M. Coomes, Health Effects of 0il Shale Processing, 9th 0il Shale Symposium, Colorado School of Mines, Golden, Colorado, 29-30 April 1976. 
BNWL -2224

UC- 48

TABLE I

TRACE AND MINOR ELEMENTS IN OIL SHALE RETORTING MATERIALS FROM THE LARAMIE SIMULATED IN SITU RETORTS (IN pPM) RETORTS

\begin{tabular}{|c|c|c|c|c|c|c|c|c|}
\hline \multirow[b]{2}{*}{ ELEMENT } & \multicolumn{2}{|c|}{$\begin{array}{c}\text { RAW OIL } \\
\text { SHALE } \\
15 \text { gal } / \text { ton }\end{array}$} & \multirow{2}{*}{$\begin{array}{c}\begin{array}{c}\text { RAW OIL } \\
\text { SHALE } \\
40 \mathrm{gal} / \mathrm{lon}\end{array} \\
\text { NAA XRF }\end{array}$} & \multicolumn{2}{|c|}{$\begin{array}{l}\text { SPENT OIL } \\
\text { SHALE }\end{array}$} & \multirow{2}{*}{$\begin{array}{l}\text { CRUDE SHALE } \\
\text { OIL (RUN 13) } \\
\text { NAA }\end{array}$} & \multirow{2}{*}{$\begin{array}{l}\text { PROCESS } \\
\text { WATER } \\
\text { (RUN B) } \\
\text { NAA } \\
\end{array}$} & \multirow{2}{*}{$\frac{B C R^{*}}{\text { NAA }}$} \\
\hline & NAA & XRF & & NAA & XRF & & & \\
\hline $\mathrm{Na}$ & 16,100 & & & 23,400 & & $19.4 \pm 0.4$ & $98 \pm 1$ & 23500 \\
\hline $\mathrm{Fe}$ & 20,700 & 20,700 & 17,400 & 42,100 & 47,000 & $30 \pm 1$ & $<1$ & 95,900 \\
\hline $\mathrm{Cr}$ & 30 & & 21 & 52 & & $0.04 \pm 0.01$ & $<0.02$ & 15 \\
\hline $\mathrm{Cn}_{n}$ & 11 & & 11 & 21.1 & & $0.37 \pm 0.02$ & $0.65 \pm 0.004$ & 36 \\
\hline $\mathrm{Ni}$ & & 33 & 30 & & 70 & & & 16 \\
\hline Sc & 5.3 & & 4.9 & 9.4 & & $<0.0002$ & $0.0004 \pm 0.0001$ & 34 \\
\hline $\mathrm{Ba}$ & 320 & & 370 & 650 & & $<0.014$ & $0.13 \pm 0.02$ & 680 \\
\hline $\mathrm{Sr}$ & 440 & 380 & 490 & 1120 & 1080 & $<0.090$ & $0.150 \pm 0.05$ & 320 \\
\hline La & 15.9 & & 16.2 & 34 & & 0.0009 & 0.0017 & 24.6 \\
\hline $\mathrm{Ce}$ & 31 & & 30 & 62 & & $<0.009$ & 0.100 & 52 \\
\hline $\mathrm{Pr}$ & 3.9 & & & 7.5 & & $<0.0013$ & $<0.0006$ & 7.2 \\
\hline $\mathrm{Nd}$ & 15 & & & 30 & & $<10$ & 0.055 & 30.3 \\
\hline$S m$ & 24 & & & 4.90 & & 0.00009 & 0.00031 & 6.3 \\
\hline Eu & 0.43 & & 0.45 & 0.82 & & $<0.0002$ & 0.00029 & 1.95 \\
\hline Gd & 19 & & & 3.3 & & $<0.00065$ & 0.02 & 6.90 \\
\hline Tb & 0.26 & & & 0.51 & & 0.00006 & 0.0011 & 1.01 \\
\hline Ho & 0.33 & & & 0.78 & & $<0.0002$ & 0.00008 & 1.26 \\
\hline Er & 10 & & & 2.0 & & $<0.008$ & $<0.0015$ & 3.4 \\
\hline Tm & 0.14 & & & 0.36 & & 0.00043 & U. $003^{-}$ & 0.66 \\
\hline$Y b$ & 0.87 & & 0.8 & 18 & & $<0.0003$ & 0.00036 & 3.38 \\
\hline Lu & 0.140 & & 0.18 & 0.34 & & $<0.00003$ & 0.000090 & 0.49 \\
\hline $\mathrm{Hf}$ & 0.71 & & 1.2 & 1.3 & & $<0.004$ & $<0.004$ & 5.0 \\
\hline Ta & 0.53 & & 0.44 & 0.8 & & & & 0.90 \\
\hline Th & 4.3 & & 4.4 & 8.2 & & & & 6.5 \\
\hline$u$ & 7.0 & & 5.6 & 12.7 & & $0.0049 \pm 0.0007$ & 0.35 & 1.7 \\
\hline $\mathrm{Rb}$ & 66 & 71 & 63 & 130 & 149 & & & 53 \\
\hline $\mathrm{Cs}$ & 5.2 & & 5.2 & $8 \pm$ & & $<0.002$ & $0.007 \pm 0.002$ & 1.1 \\
\hline As & 81 & 63 & 108 & $91 \pm$ & 92 & $5.00 \pm 0.04$ & $5.89 \pm 0.04$ & 0.70 \\
\hline Sb & 3.5 & & 3.6 & 3.4 & & $0.008 \pm 0.001$ & $0.016 \pm 0.002$ & 0.69 \\
\hline ח & & 136 & 100 & & 125 & $2.70 \pm 0.08$ & $0.43 \pm 0.04$ & 130 \\
\hline $\mathrm{Br}$ & & & & & & $0.079 \pm 0.008$ & $0.28 \pm 0.01$ & 0.10 \\
\hline $\mathrm{Se}$ & & 4.3 & 6 & & 3.6 & $0.86 \pm 0.22$ & $0.98 \pm 0.76$ & \\
\hline $\mathrm{Hg}$ & 0.2 & & 0.1 & 0.003 & & $0.2 \pm 0.03$ & $0.39 \pm 0.05$ & 0.010 \\
\hline Ga & & 4.1 & 5 & & 11 & & & \\
\hline $\mathrm{Cu}$ & & 72 & 56 & & 133 & & & \\
\hline
\end{tabular}

* U. S. geological survey standard basalt bCr-1 
.

. 


\section{TABLE II}

TRACE ELEMENTS IN SHALE OIL FRACTIONS

Whole Shale $0 i 1$

(unfiltered)

Whole Shale 0il

(filter $0.45 \mu$ )

Basic Fraction

$$
0.05 \pm .01
$$

$1.6 \pm 0.3$

$1.5 \pm .4$

$\frac{\mathrm{Zn}}{3.8 \pm 13}$

$\frac{C_{0}}{0.60 \pm .02}$

Neutral Fraction

$<0.02$

$1.8 \pm 0.3$

$0.94 \pm .3$

$4.0 \pm 14$

$0.62 \pm .02$

Acidic Fraction

$0.12 \pm 0.03$

$6.5 \pm 0.3$

$1.7 \pm .6$

$21.5 \pm 1.1$

$0.25 \pm .02$

PNA Fraction

$0.02 \pm .003$

$2.8 \pm .04$

$1.0 \pm .3$

$<0.25$

$0.10 \pm .01$

$79.0 \pm 3$

$0.12 \pm .02$

$43.0 \pm 1$

$0.07 \pm .01$ 


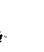




\section{INSTRUMENTAL AND RADIOCHEMICAL NEUTRON ACTIVATION \\ $1 \% \quad \mathrm{Na}, \mathrm{Sc}, \mathrm{Sm}, \mathrm{Eu}$ \\ $3 \% \quad \mathrm{Cr}, \mathrm{Co}, \mathrm{La}, \mathrm{Fe}$ \\ $5 \% \quad \mathrm{Nd}, \mathrm{Gd}, \mathrm{Tb}, \mathrm{U}, \mathrm{Th}, \mathrm{As}$ \\ $10 \% \mathrm{Pr}, \mathrm{Ho}, \mathrm{Hf}, \mathrm{Sb}, \mathrm{Yb}$ \\ 15\% Ce, Lu, Ta, Rb, Cs, Sr, Ba \\ $20 \% \mathrm{Er}, \mathrm{Tm}$}

X-RAY FLUORESCENCE

$5 \% \quad \mathrm{Sr}, \mathrm{Fe}$

$10 \% \mathrm{Rb}, \mathrm{As}, \mathrm{Zn}, \mathrm{Se}$

$20 \% \mathrm{Cr}, \mathrm{Ni}, \mathrm{Ga}, \mathrm{Cu}, \mathrm{Pb}$ 

DISTRIBUTION

No. of

Copies

OFFSITE

4

1

1

1

1

1

27

6
ERDA Chicago Patent Attorney

9800 South Cass Avenue

Argonne, IL 60439

A. A. Churm

ERDA Division of Biomedical and Environmental Research Washington, D. C. 20545

D. S. Ballantine

C. E. Carter

R. Franklin

R. W. Wood

ERDA Division of Fossil Energy Research Washington, D. C. 20545

H. E. Fisher

ERDA Office of Program Planning and Analysis - Fossil Energy Washington, D. C. 20545

M. J. Reilly

ERDA Division of Technology Overview Washington, D. C. 20545

R. Jameson

ERDA Division of Environmental Control Technology Washington, D. C. 20545

W. E. Mott

ERDA Division of Safety, Standards and Compliance Washington, D. C. 20545

L. J. Deal

ERDA Technical Information Center

ERDA Energy Research Centers

Bartlesville Energy Research Center

John S. Ball, Director

P.0. Box 1398

Bartlesville, OK 74003

Grand Forks Energy Research Center

Gordon H. Gronhovd, Director

Box 8213, University Station

Grand Forks, ND 58201 
No. of

Copies

OFFSITE

ERDA Energy Research Centers (cont.)

Laramie Energy Research Center Andrew W. Decora, Acting Director P.0. Box 3395

University Station

Laramie, WY 82070

Morgantown Energy Research Center

William T. Wertman, Acting Director

P.0. Box 880

Morgantown, WV 26505

Pittsburgh Energy Research Center

Irving Wender, Director

4800 Forbes Avenue

Pittsburgh, PA. 15213

San Francisco Energy Research Center

Oren C. Baptist, Director

1429 Appraisers Building

San Francisco, CA 94111

1 Oak Ridge National Laboratory

P.0. Box X

Oak Ridge, TN 37830

C. W. Gehrs

1 Walter Hubis

Synthetic Fuels Division

Gulf Mineral Resources Company

Gulf Building

1720 S. Bellaire Street

Denver, CO 80222

1. John Ward

Pittsburg and Midway Coal Mining Company

Solvent Refined Coal Plant

P.0. Box 199

DuPont, WA 98327

1 J. Lyn Reavis

Pittsburg and Midway Coal Mining Company

Research and Development Department

9009 W. 67th Street

Merriam, KS 66202 

No. of

Copies

\section{Battelle-Northwest}

W. J. Bair

R. M. Bean

W. D. Felix

J. S. Fruchter

J. C. Laul

S. Marks

J. M. Nielsen

R. W. Perkins

M. R. Petersen

L. A. Rancitelli

R. E. Wildung

Technical Information Files (5)

Technical Publications (1) 
